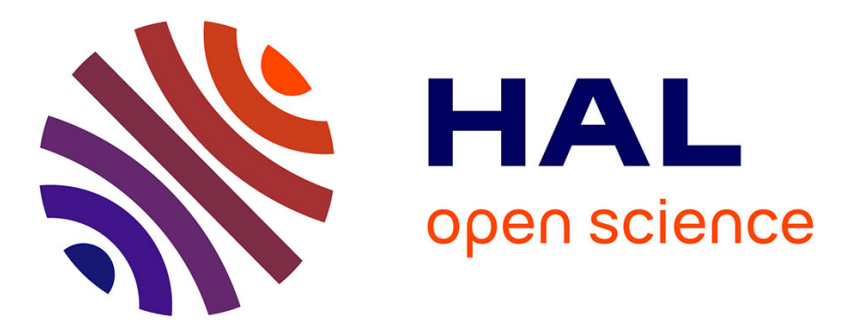

\title{
INFLUENCE OF THE FILAMENT MATERIAL ON LOW-PRESSURE HOT-FILAMENT CVD DIAMOND DEPOSITION
}

\author{
S. Okoli, R. Haubner, B. Lux
}

\section{- To cite this version:}

S. Okoli, R. Haubner, B. Lux. INFLUENCE OF THE FILAMENT MATERIAL ON LOWPRESSURE HOT-FILAMENT CVD DIAMOND DEPOSITION. Journal de Physique IV Proceedings, 1991, 02 (C2), pp.C2-923-C2-930. 10.1051/jp4:19912111 · jpa-00249790

HAL Id: jpa-00249790

https://hal.science/jpa-00249790

Submitted on 1 Jan 1991

HAL is a multi-disciplinary open access archive for the deposit and dissemination of scientific research documents, whether they are published or not. The documents may come from teaching and research institutions in France or abroad, or from public or private research centers.
L'archive ouverte pluridisciplinaire HAL, est destinée au dépôt et à la diffusion de documents scientifiques de niveau recherche, publiés ou non, émanant des établissements d'enseignement et de recherche français ou étrangers, des laboratoires publics ou privés. 
Colloque C2, suppl. au Journal de Physique II, Vo1 1, septembre 1991

\title{
INFLUENCE OF THE FILAMENT MATERIAL ON LOW-PRESSURE HOT-FILAMENT CVD DIAMOND DEPOSITION
}

\author{
S. OKOLI, R. HAUBNER and B. LUX \\ Institute for Chemical Technology of Inorganic Materials. \\ Technical University Vienna, A-1060, Vienna, Austria
}

\begin{abstract}
The behavior of $\mathrm{Re}$, Ta and $\mathrm{W}$ filaments during lowpressure hot-filament CVD diamond synthesis was investigated. With proper matching of the deposition parameters it was possible to produce uniform, well faceted diamond films on cemented carbide substrates using all three filament materials. Carbon layers were formed only on Ta filaments when using 1.0 and $2.0 \div \mathrm{CH}_{4}$ at filament temperatures below $2200^{\circ} \mathrm{C}$. No carbon layer formation was observed on $\mathrm{Re}$ and $\mathrm{W}$ filaments under these conditions.

Between 2000 and $2400^{\circ} \mathrm{C}$ the mechanical stability of the $R e$ filaments was superior to that of the Ta filaments as well as that of the $\mathrm{W}$ filaments. The $\mathrm{w}$ filaments showed the greatest deformation during the carburization.
\end{abstract}

\section{INTRODUCTION}

One of the early methods for metastable diamond synthesis was the hotfilament method /1/. As shown by Langmuir /2/ hot solid surfaces can be used to dissociate gas molecules to their atoms by a thermal process. Tungsten filaments heated in hydrogen to $3300 \mathrm{~K}$ dissociate great amounts of hydrogen molecules into atomic hydrogen.

In recent years several investigations were carried out using hotfilament techniques to study the effects of different deposition parameters on diamond formation /3-8/. It has been reported that the carburization of the filaments affects the diamond deposition /6/. The carburization behavior of $W$ and $T a$ filaments has also been investigated $/ 9 /$.

It was shown repeatedly that carbon layers can by formed on the filaments during diamond deposition. High $\mathrm{CH}_{4}$ concentrations $\left(\geq 1 \frac{1}{6}\right)$ and low filament temperatures $\left(\leq 2200^{\circ} \mathrm{C}\right)$ promote this and reduce the efficiency of the filament in decomposing the gas molecules /6,10/. In this paper differences among $W$, Ta and Re filaments with regard to diamond deposition are examined.

\section{EXPERIMENTAL DETAILS}

\subsection{Experimental set-up}

Ta, $W$ and Re wires (non-doped quality, purity: $99.85 \div \mathrm{Ta}, 99.99 \% \mathrm{~W}$ and $99.99 \% \mathrm{Re}) 0.8 \mathrm{~mm}$ in diameter and $50 \mathrm{~cm}$ long were used. The coils fabricated from these wires were $8 \mathrm{~mm}$ in diameter with 18 turns and had a final length of $5 \mathrm{~cm}$. Each such filament was fixed between 
two molybdenum electrodes (Eig.1). The power supply was kept constant using an electric power stabilizer. The filament temperature was measured optically using a two-color pyrometer (IRCON pyrometer, model Mirage OR 5 sensor).

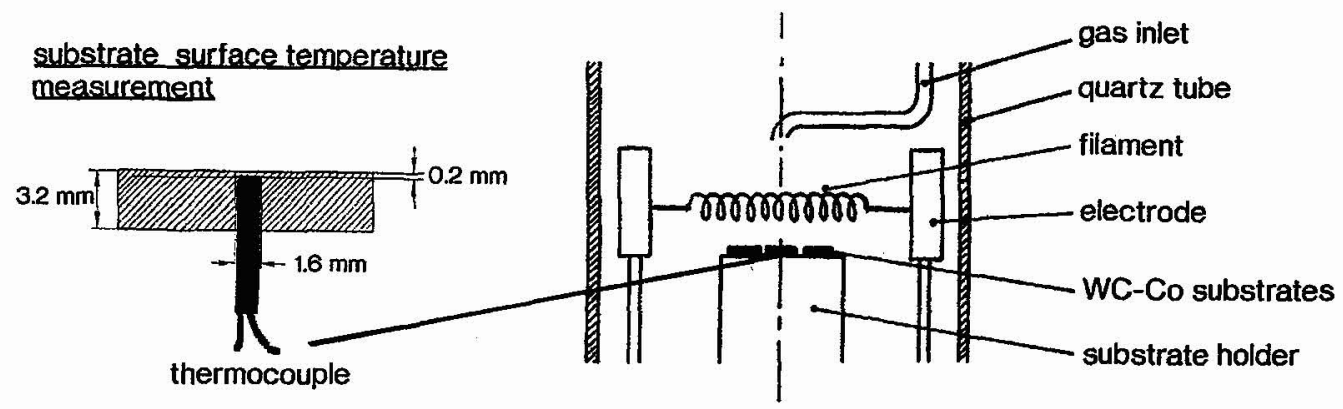

Fig.1: Experimental set-up of the hot-filament equipment

\subsection{Substrates}

The substrates used were cemented carbide inserts supplied by Sandvik Coromant, Sweden. The substrates were used wi.thout any surface pretreatment other than ultrasonic cleaning with acetone.

specification: Type HO5, shape SPUN

Composition: WC $(94.5 \mathrm{wt} \%), \mathrm{Ta}(\mathrm{Nb}) \mathrm{C}(2.0 \mathrm{wt} \%)$, Co (3.5 wt\%)

\subsection{Experimental procedure}

The tantalum and tungsten filaments used in these experiments were partially carburized $/ 9 /$. Since rhenium does not form a stable metal carbide a carburization was not necessary for these filaments.

Filament carburization conditions:

Ta filament: $14 \mathrm{~h}, 2200^{\circ} \mathrm{C}, 10$ torr $, 0.5 \% \mathrm{CH}_{4}, 301 \mathrm{H}_{2} / \mathrm{h}$

W filament: $16 \mathrm{~h}, 2000^{\circ} \mathrm{C}, 10$ torr, $0.5 \div \mathrm{CH}_{4}, 301 \mathrm{H} / \mathrm{h}$

Re filament: no carburization treatment

After this the substrates were placed on the substrate holder and the filament-substrate distance was adjusted as required. The reaction chamber was closed and evacuated for 5 minutes. The mixed gas $\left(\mathrm{CH}_{4} / \mathrm{H}_{2}=\right.$ $0.5 \%$ ) was introduced into the cold reaction chamber. After the flow rate and pressure were set, the diamond deposition was started by heating the filament to the required temperature, which was then kept constant during the run.

To increase or decrease the substrate temperature to the required value, the substrate holder was heated or water cooled. The substrate temperature was measured on the middle substrate (substrate B) by a thermocouple placed in a hole of the substrate (Fig.1).

After the desired deposition time $(8 \mathrm{~h})$ the methane flow was turned off and the substrate was allowed to cool to room temperature under pure hydrogen gas.

The depositon parameters used are summarized in Table 1.

\subsection{Analysis of the specimens}

The diamond deposits so obtained were analyzed using x-ray diffraction and scanning electron microscopy techniques.

The weights of each substrate before and after the deposition were recorded. The film thickness was measured by SEM from the cross section of the substrate. The relationship between the weight increase and the film thickness was determined to be $1 \mathrm{mg} \equiv 1 \mathrm{\mu m}$. 
Table 1: Diamond deposition parameters for testing $\mathrm{Ta}, \mathrm{Re}$ and $\mathrm{W}$

filaments. Only one process parameter was varied at a time.

Wire length

Filament-substrate distance [mm]:

Substrate surface tempemperature $\left[ \pm 10^{\circ} \mathrm{C}\right]$ :

Deposition time

Filament temperature

Pressure

Gas flow rate

Methane concentration

\section{[h]:}

$\left[{ }^{\circ} \mathrm{C}\right]$
$[\operatorname{torr}]:$
$[1 / \mathrm{h}]$
$[\%]$ 
The total gas pressure in the reaction chamber plays an important role in the formation of the active species responsible for the diamond deposition $/ 15 /$.

At higher pressures (>20 torr), less atomic hydrogen is on the substrate surface due to the lower diffusion rates and the recombination reactions /7/. The optimal substrate surface temperature at which well faceted diamond crystals will be obtained at $0.5 \% \mathrm{CH}_{4}$ increases with the gas pressure from $760^{\circ} \mathrm{C}$ (10 torr) to $810^{\circ} \mathrm{C}$ (20 torr) $/ 8 /$.

The effect of the filament material on the diamond deposition is very slight for changing gas pressures.

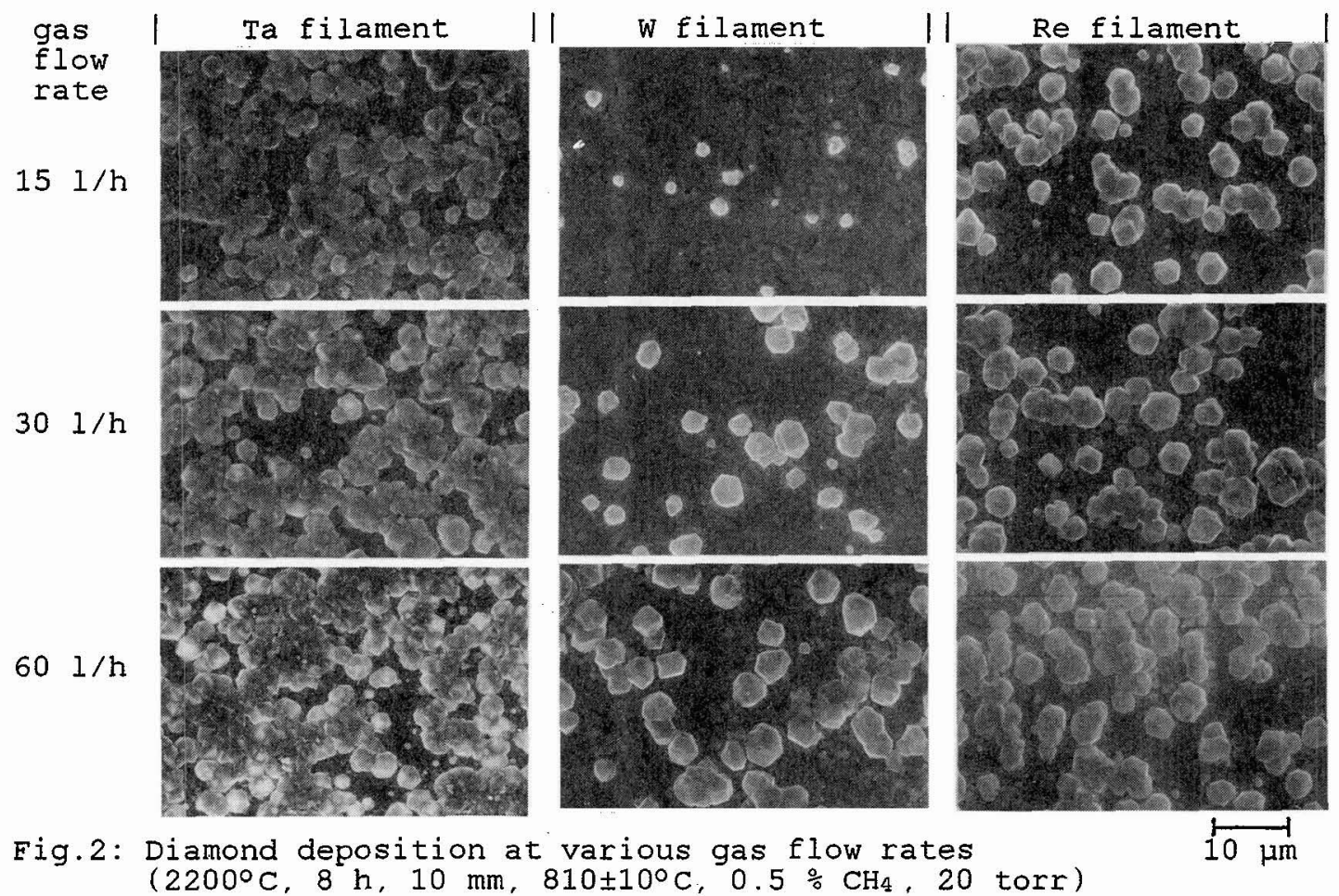

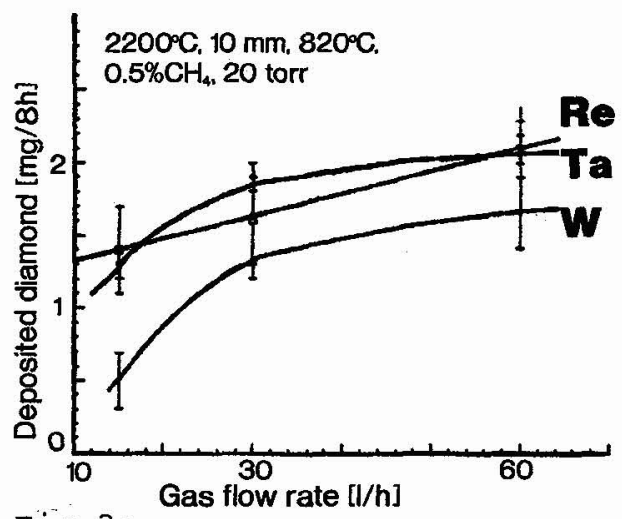

Fig. 3 :

Influence of the filament materials on diamond deposition at different gas flow rates

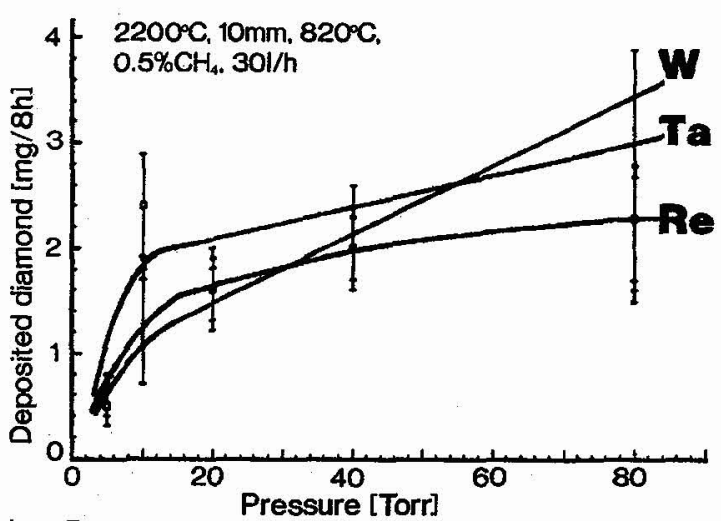

Fig. 5 :

Influence of the different filament materials on diamond deposition as a function of the gas pressure 

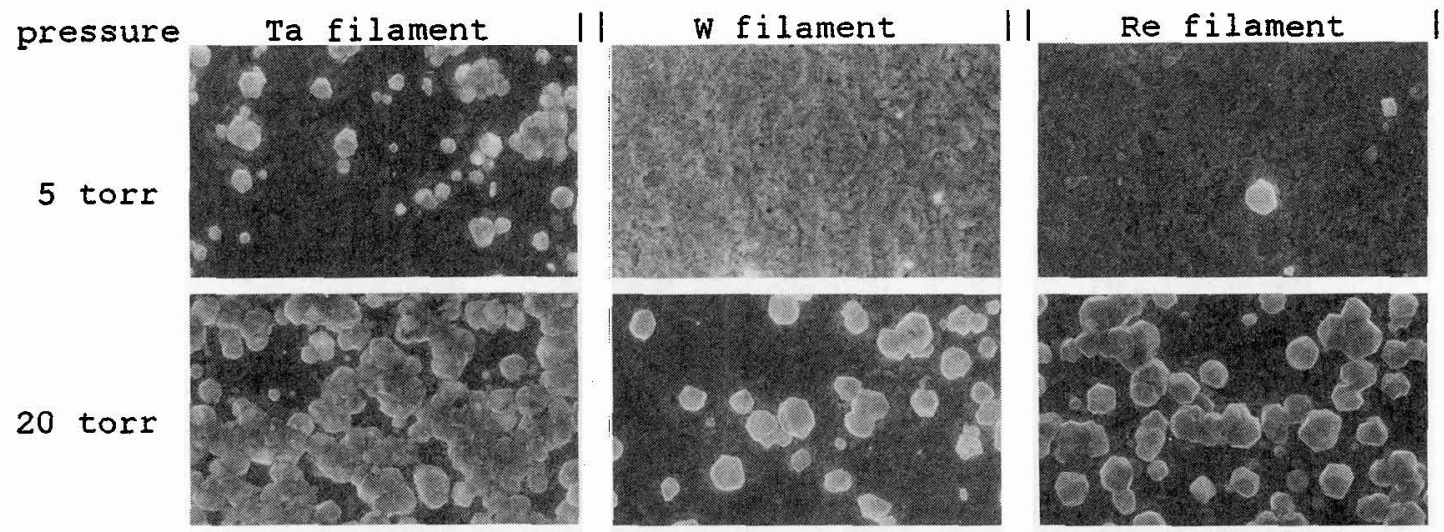

40 torr
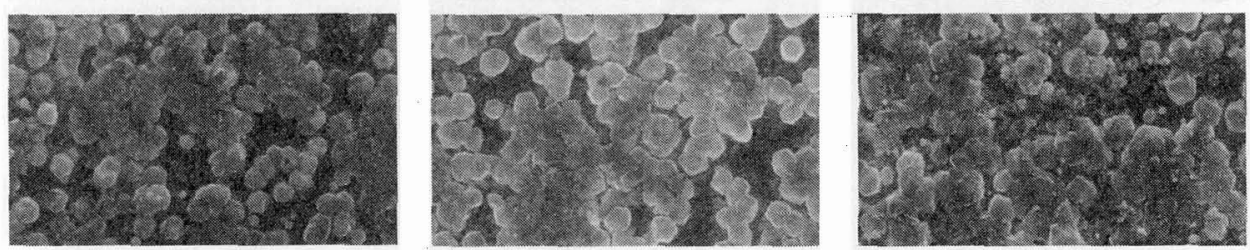

80 torr
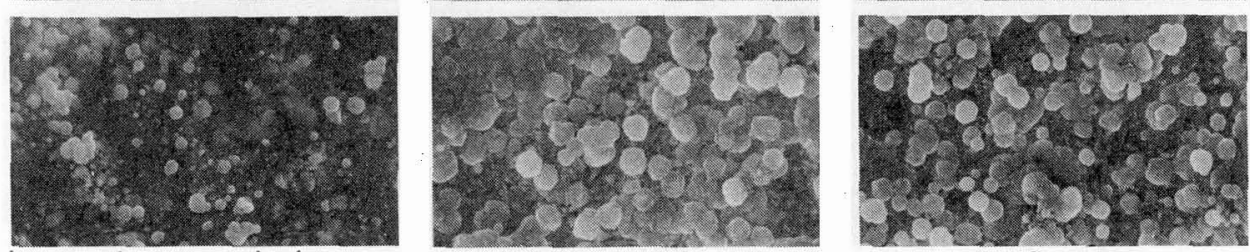

Fig.4: Diamond deposition at various gas pressures tor different filament materials $\left(2200^{\circ} \mathrm{C}, 8 \mathrm{~h}, 10^{\mathrm{mm}}, 810^{\circ} \mathrm{C}, 301 / \mathrm{h}, 0.5 \div \mathrm{CH}_{4}\right)$

Table 3: Influence of gas pressure on the diamond deposition $\left(2200^{\circ} \mathrm{C}\right.$ filament temperature, $10 \mathrm{~mm}, 0.5 \div \mathrm{CH}_{4}, 301 / \mathrm{h}$ )

\begin{tabular}{|c|c|c|c|c|c|c|}
\hline & Ta $f i 1$ & nent & $W f i$ & ament & Re $f i$ & ament \\
\hline $\begin{array}{c}\text { gas } \\
\text { pressure } \\
\text { [torr] }\end{array}$ & $\begin{array}{l}\text { depos. } \\
\text { rate } \\
{[\mathrm{mg} / 8 \mathrm{~h}]}\end{array}$ & $\begin{array}{l}\text { crystal } \\
\text { density } \\
{\left[104 / \mathrm{mm}^{2}\right]}\end{array}$ & $\begin{array}{l}\text { depos. } \\
\text { rate } \\
\text { [mg/8h] }\end{array}$ & $\begin{array}{l}\text { crystal } \\
\text { density } \\
{\left[10 \underline{0} / \mathrm{mm}^{2}\right]}\end{array}$ & $\begin{array}{l}\text { depos. } \\
\text { rate } \\
{[\mathrm{mg} / \mathrm{Bh}]}\end{array}$ & $\begin{array}{l}\text { crystal } \\
\text { density } \\
{\left[104 / \mathrm{mm}^{2}\right]}\end{array}$ \\
\hline $\begin{array}{r}5 \\
10 \\
20 \\
40 \\
80\end{array}$ & $\begin{array}{l}0.7 \\
1.8 \\
1.9 \\
2.4 \\
2.8\end{array}$ & $\begin{array}{l}<1 \\
<10 \\
>10 \\
>10 \\
>10\end{array}$ & $\begin{array}{l}0.5 \\
1.3 \\
1.4 \\
2.0 \\
2.1\end{array}$ & $\begin{array}{c}<1 \\
<10 \\
\\
>10 \\
>10\end{array}$ & $\begin{array}{l}0.5 \\
2.0 \\
1.6 \\
2.3 \\
2.4\end{array}$ & $\begin{array}{r}<1 \\
<10 \\
>6 \\
>10 \\
>10\end{array}$ \\
\hline
\end{tabular}

\subsection{Variation of the methane concentration at different filament temperatures}

The optimal filament temperature for the deposition of well faceted crystals in a diamond film depended on both the methane concentration and the filament material (Fig.6,7,8)(Table 4). The other diamond deposition parameters showed no significant effects.

Deposition at $2200^{\circ} \mathrm{C}$

There is a maximum in the diamond deposition rate when increasing the $\mathrm{CH}_{4}$ concentration for all three filament materials (Fig.7). Raising the $\mathrm{CH}_{4}$ concentration produces diamond deposits which are well faceted till the "optimal $\mathrm{CH}_{4}$ concentration" (maximum growth rate) is reached. At higher $\mathrm{CH}_{4}$ concentrations the deposits become fine grained and the 
growth rate decreases.

The optimal $\mathrm{CH}_{4}$ concentration as well as the corresponding growth rate are strongly dependent on the filament material ( $\mathrm{Ta}: 1.0 \% \mathrm{CH}_{4}$, $3.5 \mathrm{mg} / 8 \mathrm{~h}$; Re: $2.0 \% \mathrm{CH}_{4}, 7 \mathrm{mg} / 8 \mathrm{~h} ; \mathrm{W}: 2.0 \% \mathrm{CH}_{4}, 10.5 \mathrm{mg} / 8 \mathrm{~h}$ ) (Fig. 7 ). At $2200^{\circ} \mathrm{C}$ the $\mathrm{W}$ filament showed the best deposition results.

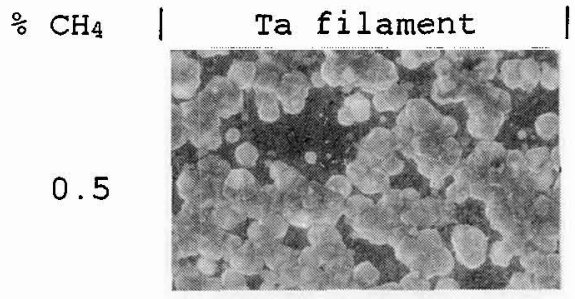

1.0

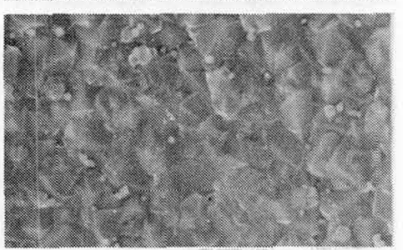

2.0

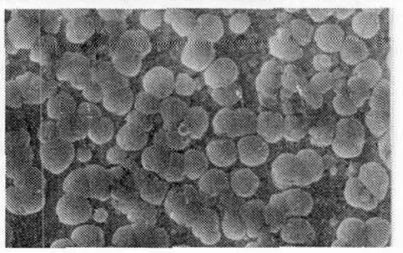

3.0

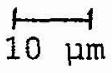

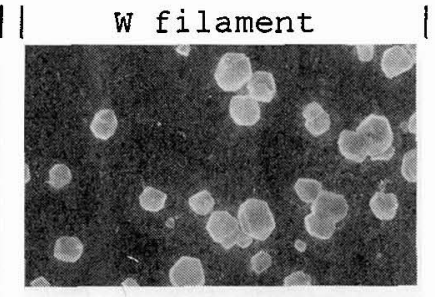
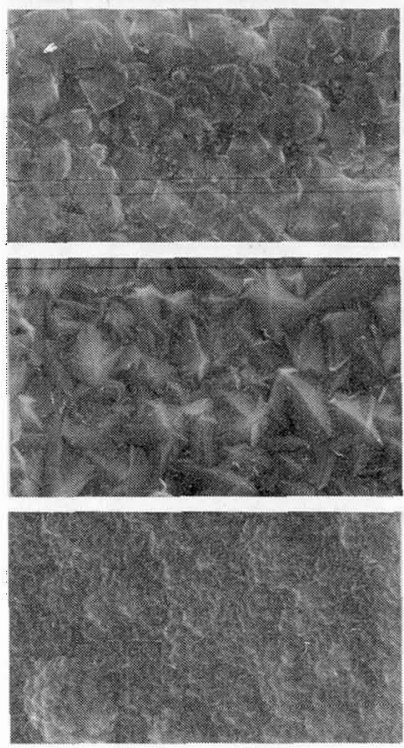
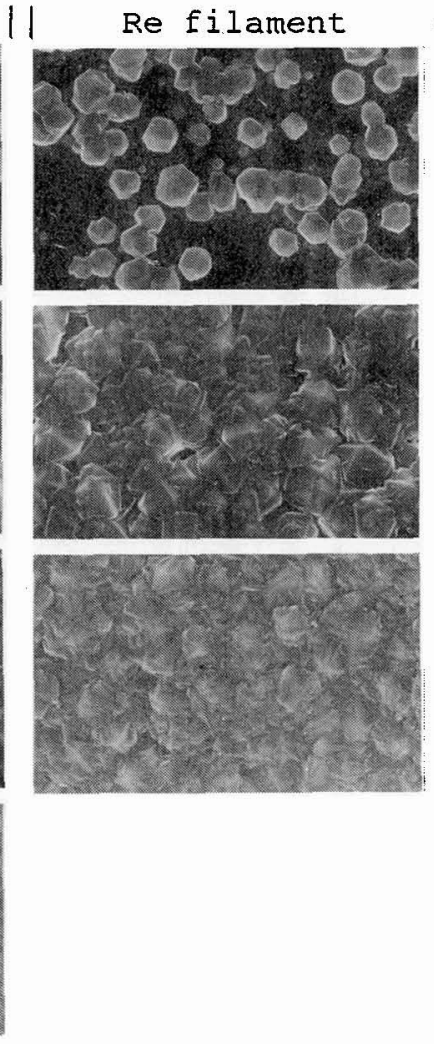

Fig.6: Influence of $\mathrm{CH}_{4}$ on diamond deposition at $2200^{\circ} \mathrm{C}$ using different filament materials $(8 \mathrm{~h}, 10 \mathrm{~mm}, 20$ torr, $30 \mathrm{l} / \mathrm{h})$
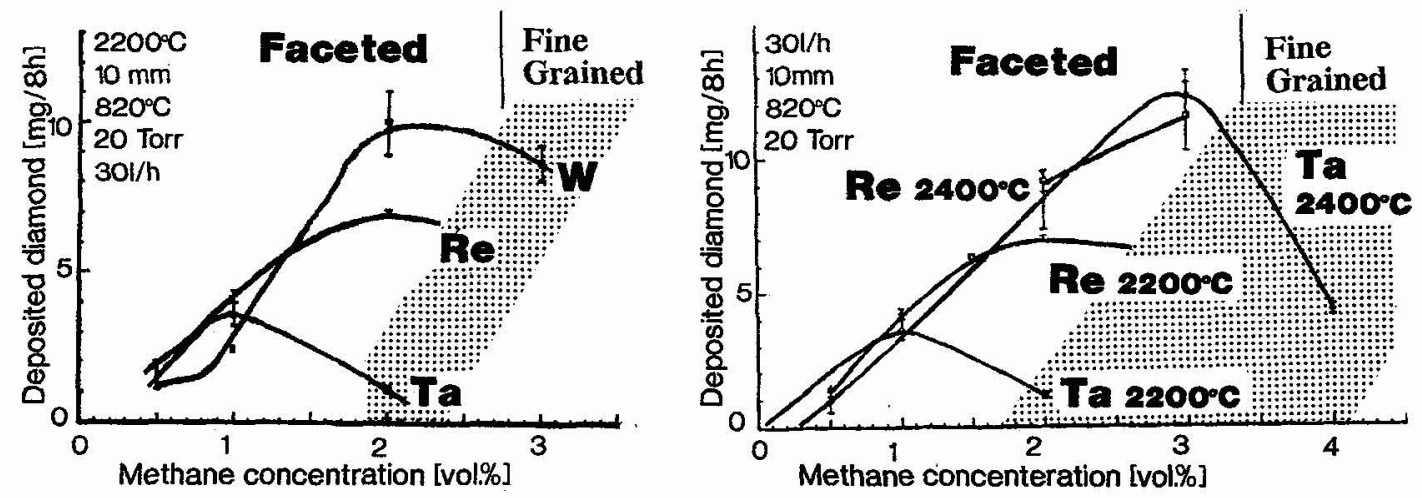

Fig. 7: Influence of filament material and $\mathrm{CH}_{4}$ concentration on diamond deposition at $2200^{\circ} \mathrm{C}$ filament temperature
Fig. 8: Comparison of diamond deposition at $\mathrm{Ta}$ and $\mathrm{Re}$ filament temperatures of 2200 and $2400^{\circ} \mathrm{C}$ with different $\mathrm{CH}_{4}$ concentrations 
Deposition at $2400^{\circ} \mathrm{C}$

Because of the low mechanical stability of the $w$ filaments diamond deposition was not possible at $2400^{\circ} \mathrm{C}$.

The experiments using $\mathrm{Ta}$ and Re filaments showed a shift of the "optimal $\mathrm{CH}_{4}$ concentration" for diamond deposition to higher concentrations (Fig.8). The large difference between the filament materials observed at $2200^{\circ} \mathrm{C}$ is absent. The optimal $\mathrm{CH}_{4}$ concentration for $T a$ filaments is $\leq 3 \%$ and for Re between 2 and $3 \%$. The maximum diamond growth rate reached was about $12 \mathrm{mg} / 8 \mathrm{~h}$ for both filament materials.

Table 4: Influence of $\mathrm{CH}_{4}$ concentration on the diamond deposition at different filament temperatures (10 mm, 20 torr, $301 / \mathrm{h}$ )

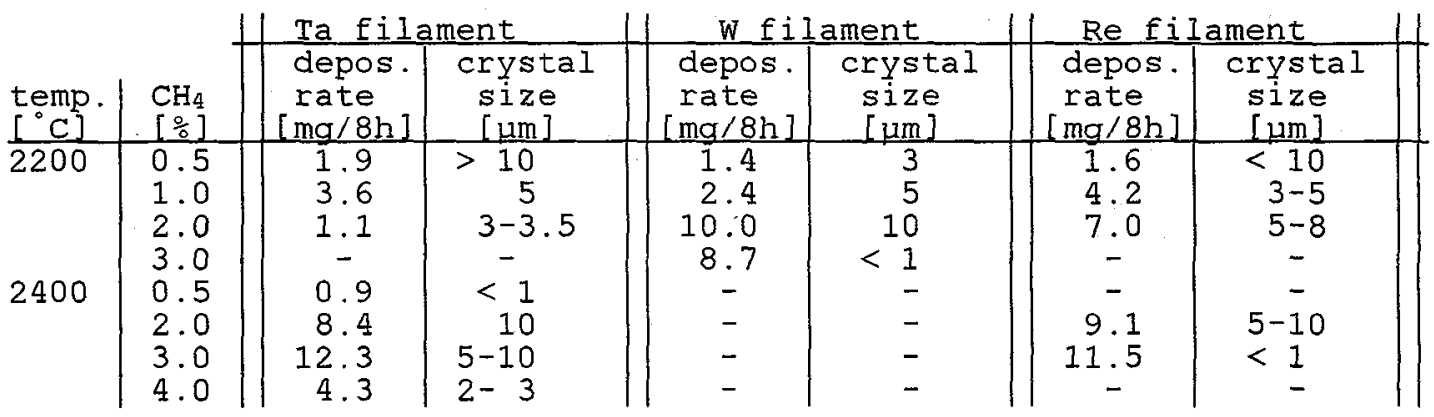

\section{COMPARISON OF THE FILAMENT MATERIALS}

- As already mentioned the filament materials did not fundamentally influence the effects of the other deposition parameters. Increasing the pressure, flow rate, filament temperature and methane concentration increased the diamond deposition rate independently of the filament material.

- The filament materials did however have a strong influence in terms of the maximum $\mathrm{CH}_{4}$ concentration at which the filament is stili active since this depends on the metal's individual thermodynamic characteristics and thus its behavior in the $\mathrm{CH}_{4} / \mathrm{H}_{2} \mathrm{mixture}$ (carbide layer formation).

- The carburization rate of a filament determines its state of deformation. W filaments carburize faster than $\mathrm{Ta}$ filaments /9/; as a result $W$ filaments deform more than Ta filaments. Using $W$ filaments for diamond deposition at $2400^{\circ} \mathrm{C}$ was impossible because of the severe filament deformation.

since Re does not form a stable metal carbide, carbon has no effect on the filament geometry.

- Mechanical stability values for Re filaments were superior to those of both $\mathrm{Ta}$ and $\mathrm{W}$ filaments. Ta and $\mathrm{W}$ filaments deform geometrically during the carburization.

Re filaments maintain their form for a long time and therefore can be used several times. Because of the carbide formation with both the Ta and $W$ filaments, they can only be used for a few times since they break during sample handling. A very stable filament holder is neccessary for a long filament lifetime.

For depositions over large area Re and Ta filaments could yield more uniform films because of the better mechanical stability.

- The economical aspects of Re and Ta filaments cannot be discussed now. Re is more expensive than $\mathrm{Ta}$, but the Re filaments can be used for a longer period than Ta filaments. The real lifetimes of $R e$ filaments were however not tested in our work. 
For all three filament materials, the proper matching of the parameters methane concentration and filament temperature made it possible to grow good quality diamond film at growth rates $>1 \mathrm{\mu m} / \mathrm{h}$.

\section{SUMMARY AND CONCLUSIONS}

- Different filament materials needed different $\mathrm{CH}_{4}$ concentrations for the deposition of well faceted good quality diamond films at high growth rates: $2200^{\circ} \mathrm{C}$ : Ta $1.0 \% \mathrm{CH}_{4}, 3.5 \mathrm{mg} / 8 \mathrm{~h}$

$$
\begin{aligned}
& \mathrm{Re} 2.0 \% \mathrm{CH}_{4}, \quad 7 \mathrm{mg} / 8 \mathrm{~h} \\
& \text { W } 2.0 \% \mathrm{CH}_{4}, 10.5 \mathrm{mg} / 8 \mathrm{~h} \\
& 2400^{\circ} \mathrm{C}: \mathrm{Ta} \leq 3 \% \cdot \mathrm{CH}_{4}, \quad 12 \mathrm{mg} / 8 \mathrm{~h} \\
& \mathrm{Re} \leq 2 \% \mathrm{CH}_{4}, \quad 12 \mathrm{mg} / 8 \mathrm{~h}
\end{aligned}
$$

- For $\mathrm{Ta}$ and Re filaments increasing the filament temperature to $2400^{\circ} \mathrm{C}$ leads to an increase in the deposition rate if the optimal methane concentration at the higher temperature is used. W filaments are not suitable for use at $2400^{\circ} \mathrm{C}$ due to severe deformation during carburization.

- Re filaments showed a superior mechanical stability over many deposition runs in contrast to $\mathrm{Ta}$ and $\mathrm{W}$ filaments.

- The general influence of the gas pressure, gas flow rate and filament temperature on the deposition of diamond are similar for all three filament materials, Ta, $W$ and $\mathrm{Re}$.

\section{ACKNOWLEDGEMENT}

The authors gratefully acknowledge the AB Sandvik coromant, stockholm, Sweden Dr.S.Söderberg for the helpful discussion.

financial support from and Dr.M.sjöstrand and

\section{REFERENCES}

1. S.Matsumoto, Y.Sato, M.Kamo, N.Setaka: Jpn.J.Appl.Phys. 21 (4) (1982) 183

2. I. Langmuir: J.Amer.Chem.Soc. 34 (1912) 860

3. E.N.Earabaugh, A.Feldman, Ir.Robins: 2nd Int.Conf of New Diamond Science and Technology, Washington D.C., Sept.23-27,1990 (in press)

4. J.C.Angus, C.C.Hayman: Science, Vol.241, Aug.1988, 913-921

5. Ching-Hsong Wu, M.A.Tamor, E.W.Kaiser: MRS Fall Meeting. Boston, $1989(F-3.20) 35$

6. R.Bichler, R.Haubner, B.Lux: High Temperature-High Pressure, Vol.21 (1989) 576-593

7. R.Litos, R.Haubner, B.Lux: High Temperature-High Pressure, Vol.22 (1990) 99-118

8. S.okoli: Doctoral Thesis TU Wien (1990)

9. S.Okoli, R.Haubner, B.Lux: $1^{\text {st }}$ Euro.Conf.on Diamond and Diamondlike Carbon Coatings, Sept.17-19, 1990, Crans-Montana (in press)

10. M.Sommer, F.W.Smith: J.Mater.Res. 5(11) (1990) 2433-2440

11. T.Anthony: Proc.NATO ASI, II Ciocco, Castellveccio Pascoli, Italy. July 22-Aug.3, 1990, Plenum Press

12. T.DebRoy, K. Tákala', W.A. Yarbrough, R.Messier: J.Appl. Phys.68(5) (1990) 2424

13. B.Lux, R.Haubner: Proc.NATO ASI, Il Ciocco, Castellveccio Pascoli, Italy, July 22-Aug. 3, 1990, Plenum Press

14. T.Anthony: MRS 1987, Nov.30-Dec.5, N 3.8 Boston, Massachusetts

15. S.okoli, R.Haubner, B.Lux: J.de Physique, 50, (5) (1989) 159-168 